\title{
COVID-19 AND IMPACT ON ENVIRONMENTAL AND INTERNATIONAL LAW IN ALBANIA
}

\author{
Phd. Candidate Erinda MISHO \\ South-Western University "Neofit Rilski”, Faculty of Law and History, Department \\ of International Law and Affairs, Blagoevgrad, Bulgaria, Environmental Law PhD \\ POLIS University, Faculty of Urban Planning and Environmental Management, \\ Department of Environmental Studies, Tirana, Albania \\ erinda_misho@universitetipolis.edu.al
}

\begin{abstract}
This paper provides an overview of the assessment of legal and policy developments of Environmental International Law on the global pandemic declared from World Health Organization on 11 march 2020. COVID-19 knows no borders, and whether these borders are international frontiers, national territories, disciplinary boundaries, either economical or industrial sectors. The COVID-19 experience has made clear that clear that environmental international law develops shifts occur in response to crises perceived as being of concern to humanity as a whole based on its unknown origins, national and international policy responses, and impact consequences on the environment. Covid-19 scenarios in Albania, including the restriction of essential and non-essential services, suspension of processing and legal terms in certain circumstances, has businesses questioning what statues, regulations, standards or policies have continued to remain in force. Generally, those environmental laws, regulations, policies, permits and standards that pertain to environmental protection, pollution prevention, biodiversity and conservation, and sustainable development whether, remain in full force and effect. At this point, it is reasonably for all business operators and companies to assume that the applicable environmental monitoring, reporting and permitting requirements continue to apply to their operations. Appropriate enforcement of the numerous environmental obligations during this emergency period will have its positive impact on environmental protection. It is important that during COVID-19, businesses continue the fully apply their current obligations and document all steps taken to maintain compliance on environmental assessment and environmental permits.
\end{abstract}

Keywords: environment, international law, covid-19 scenarios, environmental assessment

\section{Introduction}

The impact of the Coronavirus 2019 (COVID-19) pandemic, emphases that a health is a subject of both national and international concern on the whole world which it will determined challenges and amendments on the domestic and international law. World Health has declared the COVID-19 pandemic as a global health emergency. 
The Covid 19 Pandemic in March 2020 lockdown the whole world and its human activities. The disease has been spread to 210 countries so far, therefore, made it the largest pandemic in world ${ }^{1}$.COVID-19 is a zoonotic virus that currently caused with hundreds of thousands confirmed cases and thousands deaths across the globe. The origin of the virus thought to have originated from bats and that the infection appeared in China in the early 2020s. The first COVID-19 pandemic was reported in December 2019, in Wuhan, Hubei province, China and most initial cases were related to source infection from a seafood wholesale market ${ }^{2}$ (Huang et al., 2020) The impact of COVID-19 as well as global environmental changes, such as erosion, land degradation, ozone depletion, air pollution and urbanization pose a threat to our planet and human health. Global warming has its roots in industrial development, with the uncontrolled releasing of $\mathrm{CO} 2$ during the industrial activities to allowing the greenhouse effect to take place. The COVID-19 outbreak may be considered as an indirect consequence of global environmental changes in nowdays. The role of states to enforce the domestic and international environmental law and the strengthening of environmental authorities and agencies must be criteria for all country. This paper aims to study the impact of the lockdown imposed by the COVID-19 pandemic on International Environmental Law and Albanian Environmental Law starting from the modern area of developments of International Environmental Law till now and further future (Figure 1)

Figure 1. Analayzing loop of Covid 19 impact on International Environmental Law and Environmental Domectic Law (author work)

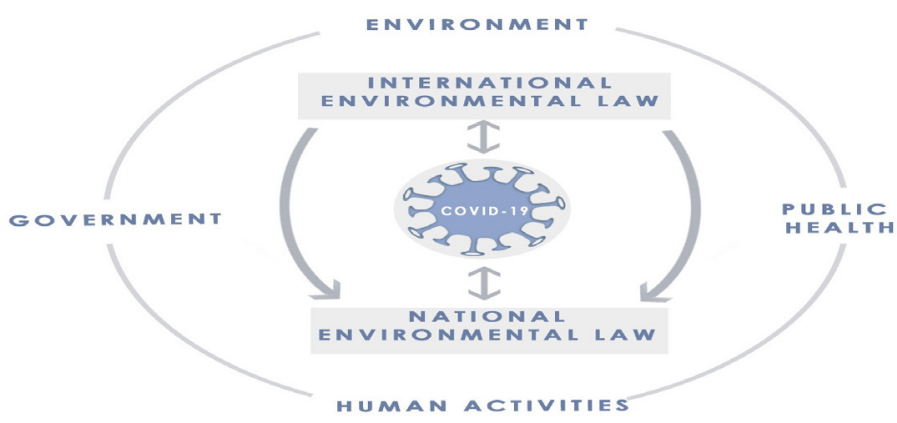

${ }^{1}($ CDC, 2020; FDA, 2020; WHO, 2020)

https://www.cdc.gov/csels/dls/locs/2020/fda updates policy about COVID-19 serology tests.html

${ }^{2}$ (Huang et al., 2020)

https://www.thelancet.com/journals/lancet/article/PIIS0140-6736(20)30183-5/fulltex 


\subsection{The International Environmental Law}

The development of modern international environmental law, starting essentially in the 1970s, since the Declaration of the 1972 Stockholm Conference on the Human Environment (UNCHE) adding that 'both aspects of man's environment, the natural and the man-made, are essential for his well-being and enjoyment of basic human rights'. ${ }^{3}$ The decade from 1980s and 1990s has seen as a development in the environmental jurisprudence because of the large number of international multilateral environmental agreements. The 1992 Rio Declaration on Environment and Development identifies many points to environmental needs, environmental protection and environmental degradation. Exactly it emphases the entirely term of Principle 1, referring instead that human beings 'are entitled to a healthy and productive life in harmony with nature .It embodied as the fundamental right of a healthy environment and it does make the link between a quality of environment and man's well being ${ }^{4}$. Primarily remains that human rights environmental law and sustainable development law are all designed to protect, inter alia human beings and human health. However understanding better the regulatory process the combination of elements whose complex inter-relationships make up the settings that the human being is the only species that has the potential to change the environment irrevocably; conversely, it is the human being alone who can take measures to protect the environment. In this context most environmental laws are aimed at controlling the activities beings focusing partly on efficiency considerations and the sustainable use of natural resources, costs of pollution damage and control, and the environmental challenges on the need to minimize the disadvantages of industrial and urban development based on environmental policy and implementation of environmental legislation. In June, 2012, countries will again meet in Rio to celebrate the 20th anniversary of the 1992 U.N. Conference on Environment and Development. Countries will focus on two aspects: 1) development and use of green technology and 2) governance and institutional issues. The field has come far since 1972. Forty years ago, environment was still a relatively obscure subject, and unknown in many countries. Some understanding on the general corpus of international environmental law where the environment can be treated from other international provisions agreements which define 'environmental effects', 'environmental impacts' or 'environmental damage' typically include harm to flora, fauna, soil, water, air, landscape, cultural heritage, and any interaction between these factors ${ }^{5}$. Environmental transboundary problems, such as air or water

\footnotetext{
${ }^{3}$ (Stockholm Declaration, Preamble, para 1, in UN, Rept of UN Conference on the Human Environment, A/CONF48/14/Rev1(NewYork,1972) http://wedocs.unep.org/xmlui/bitstream/handle/20.500.11822/28247/Stkhm_DcltnHE.pdf?sequence=1

${ }^{4}$ (Sumudu Atapattu BRILL, 2007 S.Atapattu Emerging principles of International Environmental Law pg.52

5 (1992 Convention on the Transboundary Eff ects of Industrial Accidents, Article 1 (c); 1992 Convention on the Protection of Transboundary Watercourses and Lakes, Article 1 (2); 1993 Convention on Civil Liability for Damage Resulting from Activities Dangerous to the Environment, Article 2 (7) and (10)
} 
pollution, or conservation of migratory animals, provide examples of International law to regulate environmental concerns. Some environmental problems, for example climate change or depletion of the stratospheric ozone layer, are inherently global in character and affect all states, not necessarily equally but at least to the extent that impacts are global and global solutions are required.

The Climate Change Convention the Ozone Convention, the Biological Diversity Convention, and their respective protocols, typify the emergence of such global regulatory regime against global warming alert. The UNFCC / 1992 Aricle 1 "Climate change" means a change of climate which is attributed directly or indirectly to human activity that alters the composition of the global atmosphere and which is in addition to natural climate variability observed over comparable time periods ${ }^{6}$ ". The Paris Agreement 2015 requires parties to submit mitigation-related nationally determined contributions where this new architecture is different from the model embedded in the Kyoto Protocol which set out legally binding emission reduction targets for only a limited number of countries. Increasingly, international law addresses national or domestic environmental problems, whether through international human rights law, conservation of biological diversity, protection of natural heritage areas, and promotion of sustainable development and scenarios of climate change.

\subsection{The role of law in international environmental protection}

An environmental issue can be described as 'international 'or it could be global, regional, transboundary, domestic, or a combination of all or any of these. The role played by international law in protecting the environment is not fundamentally different from, domestic or national environmental law. Based in its constitutional role international law ensures mechanisms and procedures for negotiating the necessary rules and standards, settling disputes, and supervising implementation and compliance with treaties and customary rules. In this context it facilitates the cooperation between states, international organizations, and non-governmental organizations and constitutes the processes of international environmental governance, international lawmaking and regulation. Historically international environmental law has been focused mainly on international relations and the rights and duties of states, the human-rights dimensions have become increasingly more visible. Although as national environmental law, and the international environmental law is concerned with regulating environmental problems, providing common standards and practices for prevention or mitigation of pollution, or promoting conservation and sustainable use of natural resources, biodiversity and climate changes. Strengthening the juridical regulation process and a flexible decision-making allows for regular changes in support of technological and scientific developments in the field of environment

${ }^{6}$ (UNFCC Convention)

https://unfccc.int/files/essential background/background_publications_htmlpdf/application/pdf/ conveng.pdf, 
knowledge. Changes in international law provide the flexible change of social values expressed in international politics according to current events and in the face of any situation such as the pandemic novel Covid during 2020 where they can be considered and reflected in jurisdiction, as a special point provided in international law for human rights. ${ }^{7}$

\subsection{Covid_19 and International Environmental Law}

The link between pandemics and international environmental law is sensitive and certainly belongs to the impact of pandemics on environmental protection. During the period of isolation of the planet according to WHO scenarios and isolation decision-making of different states resulted as a success story for the environment. "The COVID-19 pandemic has caused industrial activity to shut down and cancelled flights and other journeys, slashing greenhouse gas emissions and air pollution around the world. If there is something positive to take from this terrible crisis, it could be that it's offered a taste of the air we might breathe in a low-carbon future ${ }^{8 "}$. Even in the affected areas, the movement is already there limited only to those which are necessary, to take food or to take medicine. All people are encouraged to work from home. The two most affected countries are already China and Italy. Of all actions taken by the state in this short period of time, have consequences of measurable, especially in quality of environment, and the quality urban air. Change in pollution levels air, was first observed over Wuhan, China, the city which first reported incidents of new coronavirus leading to COVID-19 disease. Satellite observations revealed that the level of dioxide nitrogen (NO2) had dropped by 10 to 30 percent between January 1 and February 25. NO2 emissions produced by cars, or transport as a whole, and power plants or manufacturing industries in particular, among other activities related to people and their air emissions. While NO2 is also produced even by nature, it accounts for only one percent of total emissions. The air quality improved its quality based from the isolation of pandemic scenarios and the slowdown of economic development. The Environment during the lockdown improved its state of quality and facilitating the process of implementations of legal obligations on various environmental indicators to reach the legal criteria and EU standards according the Environmental EU Directives. "Due to pause in industrial effluent discharge into the canals of the famed canal city of Venice, Italy, its water found to glitter in March 2020. And, it was bit stinky previously but is currently visible with schooling of fish in its water along with swans hanging around enjoying the unusual urban peace and quiet. The alteration in clarity of water transparency has given a never seen offer to the locals to have a clear view of schooling of small fishes, crabs and lashing multicolored plants in the Lagoon of Venice. Due to uninterrupted boating and pollution,

\footnotetext{
${ }^{7}$ ( International Law and Environment Third Edition Birnie P., BoyleA., Redgwell C., Oxford University press 2009)

${ }^{8}$ (Environment and Energy) https://theconversation.com/uk/environment
} 
this was never possible earlier in last decades ${ }^{9 "}$ But on the other hand the impact of COVID on urban cities as the most polluted environmental areas has actually affected an increase in the number of cases of infected population as a result of air quality smoke, citing the case of cities such as Milan, Bergamo in Lombardia Region, Italy. "The effect of lockdown on air quality in Milan was assessed through the trends of 9 pollutants in meteorologically comparable periods were studied .Lockdown determined a significant reduction of PM10, PM2.5, BC, benzene, CO and NOx. $\mathrm{SO} 2$ remained unchanged in the more peripheral areas. Part of the ozone increase was probably due to the lower NO measured during lockdown. ${ }^{10 .}$. Shutdowns are likely to impact the amount of carbon in the atmosphere as well. Confronting environmental institutions in this unforeseen situation can bring environmental impacts such as emergency hospital building measures or even constructions without environmental permits and preliminary assessments.

The behavior of environmental institutions towards this unforeseen situation of pandemic can bring environmental impact, such as taking emergency measures to build hospitals or constructions without environmental permits and preliminary assessments. The difficulties of isolation bring up challenges to control various companies or human activities equipped with environmental permits how they treat their transboundary discharges according to the EU directives and Environmental domestic Law. The EU will continue to promote and uphold good governance, human rights, the rule of law, gender equality and non-discrimination, decent work conditions, as well as fundamental values and humanitarian principles. The special and extraordinary measures required to contain the pandemic must not lead to backtracking on the fundamental values and principles of our open and democratic societies. In addition, our collective coronavirus response should avoid policy and investment decisions that exacerbate existing crises such as biodiversity loss and climate emergencies. Candidate countries welcomed in the Western Balkans to the EU's Health Security Committee, providing technical assistance, crisis management protocols and guidelines, and sharing expert opinion as well as reflecting on how best associating potential candidates emergencies measures ${ }^{11}$.

\subsection{Covid-19 and impact of Environmental Law in Albania}

This pandemic is affecting territories all over the world, not recognizing nationalities or borders. On national level the Albanian government has declared the state of natural emergency as the country remains under lockdown and Covid cases and victims have been on the rise. Based on the Decision of the Council

${ }^{9}$ ((Mack, 2020) https://www.sciencedirect.com/science/article/pii/S004896972032605X

${ }^{10}$ (ARPA Lombardia, 2020b) Preliminary Analysis of Air Quality in Lombardy during the COVID-19 Emergency (In Italian). Milan. ARPA Lombardia, 2020c. Data of Air Quality in Lombardy. Available online: https://www. arpalombardia.it/Pages/Aria/Richiesta-Dati.aspx [accessed 4.12.20]

${ }^{11}$ (Communication on the Global EU response to COVID-19, Brussels, 8.4.2020) 
of Ministers No.230 of 24 march 2020" On the declaration of Natural Disaster Situation" published on the Official Gazette ${ }^{12}$, pursuant to the Law No.45/2019, "On Civil Protection", on the proposal of the Minister of Health and Social Protection and the Minister of State for Reconstruction, the Council of Ministers decided Declaration of the state of natural disaster throughout the Republic of Albania due to the epidemic caused by COVID-19.Limitation of the rights guaranteed by Articles 37, 38, 41, points 4, 49 and 51 of the Constitution ${ }^{13}$ to the extent considered necessary to achieve the protection of the health of citizens. The Inter-Ministerial Committee on Civil Emergencies (KNEC), is the highest body for coordinating the actions of state institutions and private entities, as well as the financial and material resources to cope with the natural disaster due to the epidemic caused by COVID19. Extraordinary measures have been taken to cope and mitigate the consequences of natural disaster starting with public institutions to implement plans of organizational and administrative measures to assign the state facilities under their administration responsibility, which can be made available for housing the evacuated population and limiting the activities to the necessary minimum for all public bodies.

All rights and freedoms restricted by acts, pursuant to Law No.15/2016, However, the unprecedented measures taken by governments to limit the spread of the disease have been exponentially more drastic than those designed to reduce greenhouse gas emissions. "On the prevention and fighting of infections and infectious diseases" Social lockdown is imposed on people to allow them to leave their home as infrequently as possible to shop for basic necessities such as food, to exercise each day, to collect medication or care for a vulnerable person, and to travel to and from work, but only if this is absolutely necessary and cannot be done from home ${ }^{14}$. Social lockdown is a direction for restriction of inter-individual physical interaction in order to avoid the person and outer environment. It is slightly different from curfew because under this condition, minimal emergency public movement is allowed. The self-regenerating nature to nurture her-self is overwhelming across the planet earth during quarantine and self isolated of population. The COVID-19 pandemic has brought into sharp focus the indivisibility and interdependence of all human rights. It was a real challenge in Albanian to implement national laws orders also decision of council of ministers and again it shows up the gap of how the public institutions will function during the pandemic. Based on this decision, the delayed Normative

\footnotetext{
${ }^{12}$ (Decision of the Council of Ministers No.230 of 24 march 2020" On the declaration of Natural Disaster Situation " published on the Official Gazette, pursuant to Articles 100, 170, 174, point 1, and 175, point 2, of the Constitution, and the letter "ç" of Article 18, point 1 of Article 19, and point 1 of Article 39, Law No.45/2019, "On Civil Protection”,Fletore Zyrtare e Republikës së Shqipërisë Nr. 48, Datë. 24/03/2020) https://qbz.gov.al/eli/vendim/2020/03/24/243/dc183551-1297-44e2-b35cffb33ee669c7

${ }^{13}$ (Constitution of Republic of Albania pg7-9; https://www.osce.org/albania/41888

${ }^{14}$ (Das and Paital, 2020; Paital et al., 2020) https://www.sciencedirect.com/science/article/pii/ $\underline{\text { S0048969720324311 }}$
} 
Act No.38 dated 12.05.2020 regulates the procedures how public institutions will function during covid_19 after the isolation of the country. The Ministry of Tourism and Environment has drafted only one order No.76 dated 11.03.2020. " and there is no procedure, normative act, order or decision on how environmental institutions in the country will implement environmental legislation during pandemics or how environmental impact assessments or environmental permits from companies will be reviewed and approved according to albanian environmental legislations requirements and standards. The private entities have been closed or temporarily limit their activities. Based from environmental information data ${ }^{15}$ of Environmental Protection Agency, 200(two hundred) environmental self-monitoring reports were submitted from private entities having Environmental permits during the period of covid 19 isolation. This number of reports of self-monitoring reports by companies is the same for the same period March April 2019. Law "On the environment permits" No.10448 dated 14.7.2011 amended aims at preventing, reducing and controlling the pollution caused by several activities in order to reach a high level of protection for the environment, human health and life quality concerning the complimentary penalties issued in cases of infringements. The Law provides such penalties, in addition to the monetary ones, are decided upon by the responsible State Inspectorate based on the proposal of the National Environmental Agency or the inspectors of the pertinent State Inspectorate.

"This law is fully aligned with the following directives: Directive 2008/1 / EC of the European Parliament and of the Council of 15 January 2008 "On integrated pollution control and prevention ${ }^{16}$ ", amended, Official Gazette of the European Union, no.24, dated 29.1.2008 and Directive 2001/80 / EC of the European Parliament and of the Council of 23 October 2001 "On the limitation of emissions of certain pollutants into the air by large combustion installations ${ }^{17}$,, Official Gazette of the European Union ".

\subsubsection{The question is about the credibility of environmental data from the self-monitoring reports when the private entities are closed temporarily?}

Albanian case study during lockdown April 2020;

Most of the country has been isolated due to the prevention of the Covid-19 pandemic, the inhabitants of Porto Romano area have spent days to complain because the polluted soil and water. This is due to the fact that on April 20, 2020,

\footnotetext{
15 ( State of environment Report April 2020) www.akm.gov.al

${ }^{16}$ (Directive 2008/1 / EC of the European Parliament and of the Council of 15 January 2008 "On integrated pollution control and prevention ", amended, Official Gazette of the European Union, no.24, dated 29.1.2008https://op.europa.eu/en/publication-detail/-/publication/72d5da67-0af9-4aa9-911adf3f940c1409/language-en

${ }^{17}$ (Directive 2001/80 / EC of the European Parliament and of the Council of 23 October 2001 "On the limitation of emissions of certain pollutants into the air by large combustion installations ", Official Gazette of the European Union) https://eur-lex.europa.eu/legal-content/EN/TXT/?uri=CELEX:32001L0080
} 
an irrigation canal was filled with lube oil and fuels after an industrial accident, an event which according to the residents was caused by the deposits of the oil companies. The pollution was ascertained up to 3 kilometers in the agricultural canals that serve for the drainage of the lands, which are then discharged into the Adriatic Sea. We explain that the area of Porto Romano is very close to the coastal city of Durres. Environmental experts clarified that hydrocarbons are toxic to fauna and the authorities should monitor and assess their concentration as soon as possible after discharges ascertained. According to the State Environmental Inspectorate, the oil and fuels discharge occurred from the deposits of the private company "Gega Oil", which after the accident has taken measures to clean the territory. But environmental civil society activists have reacted by saying that these measures are not enough. Meanwhile, the company denied that the oil spill had come as a result of an industrial accident ${ }^{18}$. The company explained based on environmental self-monitoring report discharges are under permitted values according to thealbanian environmental permit. We have destabilized the fragile balance of ecosystems and now we facing them from direct consequences of industrial activities environment polluted with a direct impact on our health.

\section{Conclusion}

"Covid-19 infection has emerged as a deadly infectious disease causing the greatest pandemic in the planet. The entire world including 210 nations is following lockdown with a different level of stringency to combat COVID-19 "(WHO 2020). The global community has seen the impact of international cooperation in combating health challenges Ironically, the lockdown affect to the global economy, but COVID-19 helped the Environment to improve its quality through isolation scenarios. During the countries lockdown have shown the improvements to air quality that are possible when emissions are reduced on a global and national scale. Currently it may give us time to reflect and think about environmental long-term solutions while tackling the short-term problem. The pandemic could show us how the future might look with less air, noise soil and water polluted but it should challenge governments, environmental institutions, policymakers to consider how things can be done differently to create new environmental policies after the pandemic, to hold continuously the improvements in environmental legislation. We should analyze the environmental data taking a clear view of the pandemic of covid-19, and evaluate, build and implement environmental scenarios regulations including surveillance, environmental and climate impacts, and governance-policies designed to prevent and reduction of the human healthassociated risks and improvement of the life quality of today and next generations as well as ensuring sustainable development.

\footnotetext{
${ }^{18}$ ((Environmnet Crime Digest No.1 www.recshqiperi.org) https://www.recshqiperi.org/
} 


\section{REFERENCES}

\section{Books:}

1. Birnie P., International_Environmental_Law, Th ird Edition, Oxford Press 2009 https://global.oup.com/academic/product/international-law-and-theenvironment-9780198764229?cc=al\&lang=en\&

2. JOINT COMMUNICATION TO THE EUROPEAN PARLIAMENT, THE COUNCIL, THE EUROPEAN ECONOMIC AND SOCIAL COMMITTEE AND THE COMMITTEE OF THE REGIONS Communication on the Global EU response to COVID-19 pg 3-9 https://ec.europa.eu/info/sites/info/files/ joint communication_global eu covid-19 response en.pdf

3. Sumudu Atapattu BRILL, 2007 S.Atapattu Emerging principles of International Environmental Law pg.52

4. Environmnet Crime Digest No.1 www.recshqiperi.org Porto Romano case April 2020

5. State of environment Report April 2020 www.akm.gov.al

\section{Legal Acts:}

- (1992 Convention on the Transboundary Effects of Industrial Accidents, Article 1 (c); 1992 Convention on the Protection of Transboundary Watercourses and Lakes, Article 1 (2); 1993 Convention on Civil Liability for Damage Resulting from Activities Dangerous to the Environment, Article 2 (7) and (10)

- Stockholm Declaration, Preamble, para 1, in UN, Rept of UN Conference on the Human Environment, A/CONF48/14/Rev1(NewYork,1972) http://wedocs. unep.org/xmlui/bitstream/handle/20.500.11822/28247/Stkhm_DcltnHE. pdf? sequence $=1$

- (Decision of the Council of Ministers No.230 of 24 march 2020" On the declaration of Natural Disaster Situation“ published on the Official Gazette, pursuant to Articles 100, 170, 174, point 1, and 175, point 2, of the Constitution, and the letter "ç" of Article 18, point 1 of Article 19, and point 1 of Article 39, Law No.45/2019, “On Civil Protection",Fletore Zyrtare e Republikës së Shqipërisë Nr. 48, Datë. 24/03/2020 https://qbz.gov. al/eli/vendim/2020/03/24/243/dc183551-1297-44e2-b35c-ffb33ee669c7

- (Constitution of Republic of Albania pg7-9; https://www.osce.org/ albania/41888

- Directive 2008/1 / EC of the European Parliament and of the Council of 15 January 2008 "On integrated pollution control and prevention ", amended, Official Gazette of the European Union, no.24, dated 29.1.2008https:// op.europa.eu/en/publication-detail/-/publication/72d5da67-0af9-4aa9-911adf3f940c1409/language-en 
- (Directive 2001/80 / EC of the European Parliament and of the Council of 23 October 2001 "On the limitation of emissions of certain pollutants into the air by large combustion installations ", Official Gazette of the European Union) https://eur-lex.europa.eu/legal-content/EN/ $\underline{\text { TXT/?uri=CELEX:32001L0080 }}$

\section{Website references:}

- CDC, 2020; FDA, 2020; WHO, 2020

- https://www.cdc.gov/csels/dls/locs/2020/fda_updates_policy_about COVID-19 serology tests.html

- (Huang et al., 2020) https://www.thelancet.com/journals/lancet/article/ PIIS0140-6736(20)30183-5/fulltex Clinical features of patients infected with 2019 novel coronavirus in Wuhan, China Chaolin Huang*, Yeming Wang*

- " Nurture to nature via COVID-19, a self-regenerating environmental strategyofenvironment in global context " et Paital 2020 https://www. sciencedirect.com/science/article/pii/S004896972032605X

- ARPA Lombardia, 2020b https://www.sciencedirect.com/science/article/pii/ S0048969720327972?via\%3Dihub Lockdown for CoViD-2019 in Milan: What are the effects on air quality? 